\title{
THERMAL PERFORMANCE AND CONCENTRATION OF GASES IN FACILITIES FOR PIGS IN SEMIARID REGION FROM STATE OF PARAIBA - BRAZIL ${ }^{1}$
}

\section{DERMEVAL A. FURTADO ${ }^{2}$, DANIELE AMANCIO ${ }^{3}$, JOSÉ W. B. DO NASCIMENTO ${ }^{2}$, JOSIVANDA P. GOMES ${ }^{2}$, RAFAEL C. SILVA ${ }^{4}$}

\begin{abstract}
The study was conducted in a facility for pigs during the nursery and finishing in the town of 'Montadas', in the semiarid of the state of Paraiba, Brazil, in the rainy and dry season, aiming to evaluate the concentration of oxygen, methane, carbon monoxide and ammonia, and the bioclimatic indexes: ambient temperature (AT), relative humidity $(\mathrm{RH})$ and the index of black globe temperature and humidity (IBGTH). These indexes differed significantly $(\mathrm{P}>0.05)$ between the periods and times. The AT in the rainy season was in the thermal comfort zone(TCZ) in most of the times in the nursery; for the finishing phase, thermal discomfort occurred; during the dry season, there was thermal comfort in the nursery phase; in the finishing phase the thermal discomfort occurred at all times. In the rainy season, the IBGTH was in TCZ; in the dry season, it was above the TCZ. The RH in the rainy period was in the TCZ; in the dry season, in most of the times, below the range of the TCZ. The concentration of gases showed no differences $(\mathrm{P}>0.05)$ between periods and between the times, and the carbon monoxide, hydrogen sulfide and methane were below $1.0 \mathrm{ppm}$, and the ammonia showed a mean of $5.2 \mathrm{ppm}$. None of the analyzed gases exceeded the limits established by Brazilian and international standards for animals and workers.
\end{abstract}

KEY WORDS: welfare, thermal comfort, gases, semiarid.

\section{DESEMPENHO TÉRMICO E CONCENTRAÇÃO DE GASES EM INSTALAÇÕES PARA SUÍNOS NO SEMIÁRIDO PARAIBANO}

RESUMO: A pesquisa foi desenvolvida em uma instalação para suínos, na fase de creche e terminação, no município de Montadas, semiárido paraibano, nos períodos chuvoso e seco, com o objetivo de avaliar a concentração dos gases oxigênio, metano, monóxido de carbono e amônia, e os índices bioclimáticos: temperatura ambiente (TA), umidade relativa do ar (UR) e índice de temperatura de globo e umidade (ITGU). Estes índices diferiram significativamente $(\mathrm{P}<0,05)$ entre os períodos e horários. A TA no período chuvoso ficou na zona de conforto térmico (ZCT) na maior parte dos horários na creche; para a fase de terminação, ocorreu desconforto térmico; no período seco, houve conforto térmico para a creche; na terminação, desconforto térmico em todos os horários. No período chuvoso, o ITGU ficou na ZCT; no período seco, acima da ZTC. A UR no período chuvoso esteve na ZTC; no período seco, na maior parte dos horários, abaixo da faixa da ZTC. A concentração de gases não apresentou diferenças $(P>0,05)$ entre os períodos e os horários, sendo que o valor de monóxido de carbono, gás sulfídrico e metano ficou abaixo do 1,0 ppm, e a amônia apresentou média de 5,2 ppm, sendo que nenhum dos gases analisados ultrapassou os limites estabelecidos pelas normas brasileiras e internacionais para animais e trabalhadores.

PALAVRAS-CHAVE: bem-estar, conforto térmico, gases, semiárido.

\footnotetext{
${ }^{1}$ Extraído da dissertação de mestrado da segunda autora.

${ }^{2}$ Zootecnista, Doutor em Recursos Naturais, Prof. Doutor da Unidade Acadêmica de Engenharia Agrícola,UFCG, Campina Grande PB, dermeval@ deag.ufcg.edu.br.

${ }^{3}$ Zootecnista, Mestre em Engenharia Agrícola, Doutoranda em Engenharia Agrícola na UFCG, danielleamancio@yahoo.com.br.

${ }^{2}$ Eng $^{\circ}$ Agrícola, Doutor em Engenharia de Estruturas, Prof. Doutor da Unidade Acadêmica de Engenharia Agrícola, UFCG, Campina Grande - PB, wallace@deag.ufcg.edu.br.

${ }^{2}$ Eng $^{\mathrm{a}}$ Agrícola, Doutora em Engenharia de Alimentos, Profa. Doutora da Unidade Acadêmica de Engenharia Agrícola, UFCG, Campina Grande-PB, josi@ deag.ufcg.edu.br.

${ }^{4}$ Eng $^{\mathbf{0}}$ Agrícola, Mestrando em Engenharia Agrícola na UFCG, rafael_brazil@hotmail.com.

Recebido pelo Conselho Editorial em: 13-10-2010

Aprovado pelo Conselho Editorial em: 12-9-2011
} 


\section{INTRODUCTION}

The tropical and subtropical climates of most Brazilian regions are characterized by presenting high values of temperature and relative humidity, in which often the requirements of thermal comfort, acoustic and welfare for pigs are not always answered (SILVA et al., 2007; TINÔCO et al., 2007), raising endogenous heat production, increasing the difficulty for the maintenance of homeothermic in warm or hot environments. Pigs subjected to high temperatures reduce the productive and reproductive performances; reduce the strength of the immune system, leaving them susceptible to infections, respiratory illnesses and gastrointestinal diseases (MANNO et al., 2006; SAMPAIO et al., 2007b; TINÔCO et al., 2007; TOLON et al., 2010).

Pigs, being homeotherms, have their internal body temperature constant and continually need to exchange heat with the environment; however, this process is efficient only when the ambient temperature is within the limits of thermoneutrality. According to FERREIRA (2005) the ideal temperature for pigs in the nursery phase is 22 to $26^{\circ} \mathrm{C}$, and for the finishing phase between 15 and $18{ }^{\circ} \mathrm{C}$, with relative humidity of 50 to $70 \%$. The relative humidity is essential to activate or inhibit the mechanisms of heat dissipation by evaporation, therefore, should not exceed $70 \%$. To attend the thermal comfort of the piglets, the units should provide index of black globe temperature and humidity (IBGTH) of 72 to the matrices and 80 for piglets (TURCO et al., 1995).

The key standards related to qualitative and quantitative evaluation of gas are the NR-17 (Unhealthy Activities and Operations/Brazilian Ordinance 3.214/1978 MET), CIGR (Commission Internationale du Gene Rural) and ACGIH (American Conference of Governmental Industrial Hygienists) (SAMPAIO et al., 2005). During the pig production, a large quantity of products is generated and can be harmful to the environment, to the animals and the man, that release energy, moisture, carbon dioxide, dust, and gases of digestion; indirectly other products are released from the droppings, such as heat, moisture, gases of aerobic and anaerobic digestion of waste (carbon dioxide, ammonia, hydrogen sulfide, methane) and dust from the floor, bed, food, machinery and implements used in the ration, etc. (SAMPAIO et al., 2005, 2006; PAULO et al., 2008; SILVEIRA et al., 2009).

Ammonia $\left(\mathrm{NH}_{3}\right)$ is a gas associated with reduced appetite and irritation in the mucous membranes of the pigs, and it also causes respiratory problems and lethality for workers (SAMPAIO et al., 2007a). It is produced during the biological degradation of manure, and its volatilization is influenced by high temperatures, air velocity increase and $\mathrm{pH}$. In Brazil, the NR-15 (1978) recommends a limit of $20 \mathrm{ppm}$ of $\mathrm{NH}_{3}$ to a 48-hour workweek, not exceeding $30 \mathrm{ppm}$. The tolerance to high concentrations of ammonia increases as the relative humidity increases. According to BARKER et al. (2002), with pigs exposed to $50 \mathrm{ppm}$ of $\mathrm{NH}_{3}$, there is a reduction in performance, besides the possibility of causing respiratory diseases; to $100 \mathrm{ppm}$, sneezing, salivation, and loss of appetite occur; and above $300 \mathrm{ppm}$, there is irritation in the respiratory system and seizures.

Hydrogen sulfide $\left(\mathrm{H}_{2} \mathrm{~S}\right)$ has a characteristic and unpleasant odor, even at low concentration, and, in buildings for animals, $\mathrm{H}_{2} \mathrm{~S}$ is found with concentration lower than that of other pollutant gases such as ammonia $\left(\mathrm{NH}_{3}\right)$, carbon dioxide $\left(\mathrm{CO}_{2}\right)$ (CIGR, 1994). BARKER et al. (2002) report that concentrations of $200 \mathrm{ppm}$ of $\mathrm{H}_{2} \mathrm{~S}$ could cause pulmonary edema, respiratory distress and even the death of the animal, and the environment contributes to accelerate the corrosion of metals, because it is reactive, undesirable characteristic due to the metal structure be quite normal in buildings intended for confinement of animals. Methane is a colorless gas, has no odor, color or taste, is lighter than air, has low toxicity, and is mainly produced in the fermentation of the manure (SAMPAIO et al., 2007b).

The objective of this study was to evaluate the environmental indicators and the level of gases in pig shed in semiarid of the state of Paraíba, in dry and rainy periods. 


\section{MATERIAL AND METHODS}

This study was carried out in a shed of pigs belonging to the Company Avezen Ltda., located in the municipality of Montadas, state of Paraíba, Brazil, located at $07^{\circ} 1^{\prime} 30^{\prime \prime}$ south latitude and $35^{\circ} 90^{\prime} 00^{\prime \prime}$ west longitude, with an average height of $713 \mathrm{~m}$, inserted in the semiarid region of Paraíba, in winter conditions (rainy season) and summer (dry season).

The building had a total area of $421.4 \mathrm{~m}^{2}(31.1 \times 31.1 \mathrm{~m})$, oriented east-west, built in masonry walls, concrete columns, $2.45 \mathrm{~m}$ ceiling height, pitched roof, covered with ceramic tile resting on wooden trusses.

The herd was composed of crossbred of Landrace, Large White and Duroc, of which 157 animals were housed in the rainy season and 198 in the dry season. The shed was made up of nine bays, with concreted floor area of $48.98 \mathrm{~m}^{2}(7.9 \times 3.5 \mathrm{~m})$, internal low walls of $0.80 \mathrm{~m}$ and central corridor of $1.10 \mathrm{~m}$ wide; and the feeders were made of masonry. The low walls outside the barn were $1.10 \mathrm{~m}$ tall, with galvanized wire screens to the roof height, with yellow polyethylene curtains, and the shed cleaning was done twice a day. The water was supplied in troughs like pacifiers and the feeding system performed manually, from $9 \mathrm{am}, 11 \mathrm{am}$ and 3:30 pm.

The collections of dry bulb temperature $\left(\mathrm{t}_{\mathrm{db}}\right)$, wet bulb temperature $\left(\mathrm{t}_{\mathrm{wb}}\right)$ and black globe temperature $\left(\mathrm{t}_{\mathrm{bg}}\right)$, were registered every hour throughout the experiment with interval, from 7 am to 5 pm, using data logger, HOBO H08-006-04 model, with four channels and four sensors, with electronic monitoring of the data, stored in the device memory. With data from the dry bulb temperature, wet bulb temperature and black globe temperature, it was calculated the relative humidity, using equations cited by VAREJÃO-SILVA (2000), described below:

$$
\mathrm{RU}=\frac{\mathrm{e}}{\mathrm{e}_{\mathrm{s}}} 100
$$

In which $\mathrm{RH}$ is given in $\%$; $e$ is the partial pressure of water vapor and $e_{s}$ is the saturation pressure of water vapor, both expressed in $\mathrm{hPa}$, calculated by the following equations:

$$
\begin{aligned}
& \mathrm{e}=\mathrm{e}_{\mathrm{s}}\left(\mathrm{T}_{\mathrm{w}}\right)-0.00066 \mathrm{P}_{0}\left(1+0.00115 \mathrm{~T}_{\mathrm{w}}\right)\left(\mathrm{T}_{\mathrm{a}}-\mathrm{T}_{\mathrm{w}}\right) \\
& \mathrm{e}_{\mathrm{s}}=6.1078 \exp ^{\left[\frac{17.26938 \mathrm{~T}}{\mathrm{~T}_{\mathrm{a}}+237.3}\right]}
\end{aligned}
$$

In which $\mathrm{e}_{\mathrm{s}}\left(\mathrm{T}_{\mathrm{w}}\right)$ is the saturation pressure of water vapor to the wet bulb temperature, $\mathrm{P}_{0}$ is the local atmospheric pressure in $\mathrm{hPa}$;

The temperature of the dew point was calculated using the analytical method reported by VAREJÃO-SILVA (2000), according to the following expression:

$$
\mathrm{T}_{\mathrm{d}}=237.3 \ln \left(\frac{\mathrm{e}}{6.1078}\right) /\left(17,269-\ln \left(\frac{\mathrm{e}}{6.1078}\right)\right.
$$

in which $e$ is the vapor pressure, obtained using eq.(3).

The index of black globe temperature and humidity (IBGTH) - obtained by the eq.(5), developed by BUFFINGTON et al. (1981):

$$
\mathrm{IBGTH}=\mathrm{t}_{\mathrm{bg}}+0.36 \mathrm{t}_{\mathrm{dp}}-330.08
$$

In which $\mathrm{t}_{\mathrm{bg}}$ - temperature of the globe; $\mathrm{t}_{\mathrm{dp}}$ - temperature of dew point, calculated in $\mathrm{K}$.

Measurements of oxygen gas $\left(\mathrm{O}_{2}\right)$, ammonia $\left(\mathrm{NH}_{3}\right)$, methane $\left(\mathrm{CH}_{4}\right)$ and carbon monoxide (CO) inside the stalls were held from 7 am to $3 \mathrm{pm}$, three times a week, using a portable digital gas monitor, configured for continuous reading of gases. During measurements of gases, the detector 
was positioned at two points: the first at $1.5 \mathrm{~m}$, the height level of the handler, and the other in the center of mass of the pigs, at the pigs' height, in various parts of the animal shelter; the results presented and discussed correspond to the mean of these values.

The experimental design was completely randomized (DCR) to environmental parameters (AT, IBGTH and RH) in a factorial ( $2 \times 11)$, in which there were 2 seasons and 11 times; for gases in a factorial $(2 \times 4)$, in which there were 2 seasons and 4 assessed times, performed by the statistical program SAEG (1993). The data were submitted to ANOVA, and means were compared by Tukey test at $5 \%$ significance level.

The statistical model used in the analysis is given by eq.(6):

$$
\mathrm{y}_{(\mathrm{ijk})}=\mathrm{m}+\mathrm{a}_{\mathrm{i}}+\mathrm{b}_{\mathrm{j}}+(\mathrm{ab})_{\mathrm{ij}}+\mathrm{e}_{(\mathrm{ijk})}
$$

In which: $\mathrm{m}$ - mean; $\mathrm{a}$ - a factor effect (station); $\mathrm{b}$ - b factor effect (times); $\mathrm{ab}$ - interaction effect; e - experimental error.

\section{RESULTS E DISCUSSION}

There is a significant difference $(\mathrm{P}<0.05)$ between seasons (rainy and dry) and times (Table 1). Analyzing the values of ambient temperature (AT) and taking as basis the values of the thermal comfort zones (TCZ), for pigs in the nursery and finishing phase, quoted by FERREIRA (2005) it was noted that in the rainy season, in the nursery phase, in most times there was comfort, because in this period, in semiarid region, warmer temperatures occur. These values were similar to those reported by CAMPOS et al. (2009), in a research on pig nursery in the winter; in the dry season, only at 7;8; 9 am and $5 \mathrm{pm}$, there was thermal comfort, which according to FERREIRA (2005) should be between 22 to $26^{\circ} \mathrm{C}$. The maintenance of the piglets in their thermal comfort zones is important so that the absorbed nutrients are used for body growth and not for thermogenesis.

TABLE 1 . Mean values of the ambient indexes in the rainy and dry season.

\begin{tabular}{|c|c|c|c|c|c|c|}
\hline \multirow{2}{*}{ Time } & \multicolumn{2}{|c|}{ Air Temperature $\left({ }^{\circ} \mathrm{C}\right)$} & \multicolumn{2}{|c|}{ Relative Humidity $\left({ }^{\circ} \mathrm{C}\right)$} & \multicolumn{2}{|c|}{$\begin{array}{c}\text { Index of Black Globe } \\
\text { Temperature and Humidity }\end{array}$} \\
\hline & $\begin{array}{l}\text { Rainy Season } \\
\text { (winter) }\end{array}$ & $\begin{array}{c}\text { Dry Season } \\
\text { (summer) }\end{array}$ & $\begin{array}{l}\text { Rainy Season } \\
\text { (winter) }\end{array}$ & $\begin{array}{c}\text { Dry Season } \\
\text { (summer) }\end{array}$ & $\begin{array}{l}\text { Rainy Season } \\
\text { (winter) }\end{array}$ & $\begin{array}{c}\text { Dry Season } \\
\text { (summer) }\end{array}$ \\
\hline $7 \mathrm{am}$ & $19.35 \mathrm{f} \mathrm{B}$ & 24.02 e A & $74.21 \mathrm{a} \mathrm{A}$ & 69.09 a A & $74.19 \mathrm{f} \mathrm{A}$ & $75.30 \mathrm{~d} \mathrm{~A}$ \\
\hline 8 am & & & & & 75.33 ef $B$ & 77.48 \\
\hline 9 am & & & & & $76.58 \mathrm{~d}$ & $77.55 \mathrm{~cd} \mathrm{~A}$ \\
\hline $10 \mathrm{am}$ & & $\operatorname{abcd} \mathrm{A}$ & $60.26 \mathrm{bcd} A$ & & $77.30 \mathrm{~b}$ & $79.32 \mathrm{abc} A$ \\
\hline $11 \mathrm{am}$ & $24.10 \mathrm{abc} B$ & & $58.85 \mathrm{bcd} A$ & & $78.10 \mathrm{ab}$ & $80.42 \mathrm{ab} \mathrm{A}$ \\
\hline $12 \mathrm{pm}$ & & & & & $79.28 \mathrm{a}$ & 81.36 a A \\
\hline $1 \mathrm{pm}$ & & & & & 79.48 a B & 82.09 a A \\
\hline $2 \mathrm{pm}$ & & & & & 77.08 cde I & 81.98 a A \\
\hline $3 \mathrm{pm}$ & & & & & 78.27 abcd B & 81.99 a A \\
\hline $4 \mathrm{pm}$ & & 27.94 abc A & 58.75 bcd A & 44.72 cde $B$ & 78.70 abc B & $80.84 \mathrm{ab} A$ \\
\hline $5 \mathrm{pm}$ & $22.63 \mathrm{~cd} \mathrm{~B}$ & $26.87 \mathrm{bcd} A$ & $65.86 \mathrm{abc} A$ & 52.77 bc B & 77.99 abcd A & $78.42 \mathrm{bc} \mathrm{A}$ \\
\hline
\end{tabular}

Means followed by the same lower-case letter in the column and capital letter in the row do not differ at $5 \%$ of probability by the Tukey test.

In the finishing phase, it was observed thermal discomfort in the two periods and at all times analyzed, including the animals at certain times, at temperatures above $28{ }^{\circ} \mathrm{C}$, and based upon the recommendations of FERREIRA (2005), which mentions that the ideal temperature for the finishing phase should be between 15 and $18^{\circ} \mathrm{C}$. It is observed that the temperature, especially in the dry season, was more than $11^{\circ} \mathrm{C}$ above the recommended. When growing pigs are subjected to high temperatures, there is a reduction in performance (KIEFER et al., 2005), mainly by reducing food 
consumption and the energy cost associated to the processes of thermoregulation (MANNO et al, 2006), in which the animals tend to lose efficiency of available energy utilization as mechanisms of thermoregulation are trigger to reduce the impact of the hot ambient on their body.

For the RH, it was observed in the rainy season the highest values, ranging from 53.27 to $74.21 \%$; in the dry season, the values ranged from 35.77 at $12 \mathrm{pm}$, with lower value $(69.09 \%)$ at $7 \mathrm{am}$. The values of RH in the rainy season are within the limits of thermoneutrality for pigs, which, according to FERREIRA (2005), are considered ideal from 50 to $70 \%$; but in the dry season, in most of the times, the RH was below the ideal, reaching the values at 11 am (38.67\%) and $2 \mathrm{pm}$ (38.10\%), which can be considered critical, since they affect thermoregulation of animals, making the exchange of sensible and latent heat difficult.

TOLON et al. (2010) reported that the relative humidity interferes with the reproductive efficiency of male pigs and, when combined with high temperatures, affects the sperm morphology, which is one of the biggest problems affecting sexually active males' pigs, since the stress induces excessive production of corticosteroids.

In the rainy season, the IBGTH reached the highest value at $1 \mathrm{pm}$ and the lowest at $7 \mathrm{am}$, and in the dry season ranged from 75.33 (at $7 \mathrm{am}$ ) to 79.48 (at $1 \mathrm{pm}$ ), and the values at both seasons during the day were increasing until $3 \mathrm{pm}$ and, from $4 \mathrm{pm}$, falling. In a research conducted by TURCO (1998), the upper limit of thermal comfort for finishing pigs, based on IBGTH, equals 72; so it is observed that in both periods the IBGTH was above the recommended.

This tendency of IBGTH increase throughout the day and above the thermal comfort zone for pigs, are also reported by SAMPAIO et al. (2006) in studies with pigs in the nursery and termination phase, and by TINOCO et al. (2007) and CORDEIRO et al. (2007), which in researches in the summer and spring, respectively, cite high levels of IBGTH and above the thermal comfort zone. It was also observed that the hottest times of the day, the animals had accelerated and constant panting, showing thermal discomfort and highlighting the need to improve the bioclimatic conditions of facilities, such as the use of landscaping stock, artificial ventilation and evaporative cooling such as nebulizers, which could provide improved thermal environmental conditions, a fact observed by FURTADO et al. (2006) and JACOME et al. (2007), analyzing the environment for broilers and laying hens, respectively, also in semi-arid region of Paraíba.

The average concentrations of hydrogen sulfide $\left(\mathrm{H}_{2} \mathrm{~S}\right)$, methane $\left(\mathrm{CH}_{4}\right)$, carbon monoxide (CO) and oxygen $\left(\mathrm{O}_{2}\right)$ in the installation of the nursery and finishing barn are shown in Table 2. The average concentrations of $\mathrm{H}_{2} \mathrm{~S}$ and $\mathrm{CO}$ were below $1 \mathrm{ppm}$ and $\mathrm{CH}_{4}$ below $0.1 \mathrm{ppm}$ (corresponding to the resolution limit of the instrument), and these concentrations are within the limits recommended by CIGR (1994), for the animals, and limits recommended by the NR-15 (1978) and ACGIH (2001) for the worker, characterizing the environment as wholesome. These values may be related to the facilities where the animals were housed, since it was open with good ventilation (SAMPAIO et al., 2005; 2006; 2009; CAMPOS et al., 2009; SILVEIRA et al., 2009). The $\mathrm{O}_{2}$ values remained constant at a level of $21 \%$, being into the condition of wholesomeness. When $\mathrm{O}_{2}$ is at the appropriate level within the installations, this may be an indication that there is no risk to the environment for the presence of nerve gases $\left(\mathrm{CH}_{4}\right.$ and $\left.\mathrm{CO}_{2}\right)$, which displace oxygen. These values were similar to those reported by SAMPAIO et al. (2005), researching nursery and finishing, and SILVEIRA et al. (2009), work in pig nurseries of different types. 
TABLE 2. Mean concentration of hydrogen sulfide $\left(\mathrm{H}_{2} \mathrm{~S}\right)$, methane $\left(\mathrm{CH}_{4}\right)$, carbon monoxide $(\mathrm{CO})$, oxygen $\left(\mathrm{O}_{2}\right)$ and ammonia $\left(\mathrm{NH}_{3}\right)$.

\begin{tabular}{lcccc}
\hline & \multicolumn{4}{c}{ Times and Concentration of Gases } \\
\hline Gases & $7: 30 \mathrm{am}$ & $10: 30 \mathrm{am}$ & $1: 30 \mathrm{pm}$ & $2: 30 \mathrm{pm}$ \\
$\mathrm{H}_{2} \mathrm{~S}(\mathrm{ppm})$ & $<1$ & $<1$ & $<1$ & $<1$ \\
$\mathrm{CO}(\mathrm{ppm})$ & $<1$ & $<1$ & $<1$ & $<1$ \\
$\mathrm{CH}_{4}(\mathrm{ppm})$ & $<0.1$ & $<0.1$ & $<0.1$ & $<0.1$ \\
$\mathrm{O}_{2}(\%)$ & 21 & 21 & 21 & 21 \\
$\mathrm{NH}_{3}(\mathrm{ppm})$ & $5.1 \mathrm{ab}$ & $4.7 \mathrm{~b}$ & $5.9 \mathrm{a}$ & $4.9 \mathrm{~b}$ \\
\hline
\end{tabular}

Means followed by the same letter do not differ at $5 \%$ of probability by the Tukey test.

The ammonia concentration did not differ between the rainy and dry season $(\mathrm{P}>0.05)$, and there was a significant difference between times $(\mathrm{P}<0.05)$, but all were below the international recommendations (CIGR, 1994; ACGIH, 2001) and the standard NR-15 (1978), which regulates the exposure of workers to be aggressive in Brazil, mentioning that the average concentration of $\mathrm{NH}_{3}$ during the working day of eight hours daily, must be a maximum of $20 \mathrm{ppm}$; it was also lower the value suggested by researchers from Europe, which is approximately $10 \mathrm{ppm}$ (HEBER et al., 2002). This difference in concentration of $\mathrm{NH}_{3}$ between the hours was also observed by SILVEIRA et al. (2009) and CAMPOS et al. (2009), in researches of pigs nursery. This low concentration of $\mathrm{NH}_{3}$ may be associated with the types of facilities, which had side vents, good natural ventilation system, and health care management. These low values of ammonia inside the facilities are necessary for animal welfare and, according to BARKER et al. (2002), exposure to concentrations above 6 ppm leads to irritation of mucous membranes and exposures above $20 \mathrm{ppm}$ causes eye irritation and respiratory problems.

This concentration of $\mathrm{NH}_{3}$ similar in the dry season (summer) and rainy (winter) is in disagreement with other work, such as SAMPAIO et al. (2007b), citing higher levels of $\mathrm{NH}_{3}$ in the winter, and this fact justifies the conditions of climate and management at this time of year, like the closing of facilities, which favors the formation of ammonia and, consequently, a higher concentration. However, PAULO et al. (2008), reported that ammonia levels are higher in summer, and this increase is associated to the fact that the animals ingest a larger amount of water and the need for constant power, a scenario that also generates increased production of solid and liquid waste and, consequently, increased production of gas on the installations. This variation in the concentration of $\mathrm{NH}_{3}$ is associated with the types of facilities, which in arid and semiarid regions are generally open to the management and mainly to climatic factors, which are different in each region.

These low values of $\mathrm{NH}_{3}$ are consistent with those discussed by SILVEIRA et al. (2009), CAMPOS et al. (2009), in studies conducted in pig nursery with different types in southeastern Brazil, but also by PAULO et al. (2008), analyzing the emission of ammonia in the southern region of Brazil, for different types of superimposed bed, which reported values of ammonia concentration below that are recommended by the NR-15 (1978) and ACGIH (2001). TOLON et al. (2010) also reported low levels of $\mathrm{NH}_{3}$ (mean $2.0 \mathrm{ppm}$ ) in pig breeding facilities.

\section{CONCLUSIONS}

The ambient temperature and the index of black globe temperature and humidity during the rainy season within the nursery provided better thermal comfort than in the dry season, and in the finishing phase, in both periods, there were thermal discomfort.

The relative humidity remained within the limits of thermoneutrality during the rainy season and the dry season, was in most times, below the range of thermal comfort.

The concentration of gases in the environment, both during dry and rainy, was considered wholesome for animals and workers do not indicate problems with open facilities. 


\section{ACKNOWLEDGE}

The authors thank CNPq for the funding of this research.

\section{REFERENCES}

ACGIH - AMERICAN CONFERENCE OF GOVERNMENT INDUSTRIAL HYGIENISTS. TLVs and BEIs - Threshold limit values for chemical substances and biological exposure indices. Cincinnati, 2001. 185 p.

BARKER, J.; CURTIS, S.; HOGSETT, O.; HUMENIK, F. Waste quality \& waste management: Safety in swine productions systems. North Caroline: Cooperative Extension service, 2002. Benedi, J. M.H. El ambiente de los alojamientos ganaderos. Hojas Divulgadoras, Madrid, v.6, n.1, p.286, 2002.

BUFFINGTON, D.E.; COLLASSO-AROCHO, A.; CANTON, G.H.; PIT, D. Black globe-humidity index (BGHI) as comfort equation for dairy cows. Transactions of the ASAE, St. Joseph, v.24, n.3, p.711-714, 1981.

CAMPOS, J.A.; TINÔCO, I.F.F.; BAÊTA, F.C.; CECON, P.C.; MAURI, A.L. Qualidade do ar, ambiente térmico e desempenho de suínos criados em creches com dimensões diferentes. Engenharia Agrícola, Jaboticabal, v.29, n.3, p.339-347, 2009.

CIGR - COMMISSION INTERNATIONALE DU GÉNIE RURAL. Aerial environment in animal housing: concentrations in and emissions from farm buildings. Dublin, 1994. 116 p.

CORDEIRO, M.B.; TINÔCO, I.F.F.; OLIVEIRA, P.A.V. de; GUIMARÃES, M.C.C.; BAÊTA, F.C.; SILVA, J.N. Efeito de sistemas de criação no conforto térmico ambiente e no desempenho produtivo de suínos na primavera. Revista Brasileira de Zootecnia, Viçosa-MG, v.35, n.5, p.1597$1602,2007$.

FERREIRA, R.A. Maior produção com melhor ambiente para aves, suínos e bovinos. Viçosa: Aprenda Fácil, 2005. 371 p.

FURTADO, D.A.; DANTAS, R.T.; NASCIMENTO, J.W.B. Efeitos de diferentes sistemas de acondicionamento ambiente sobre o desempenho produtivo de frangos de corte. Revista Brasileira de Engenharia Agrícola e Ambiental, Campo Grande, v.10, n.2, p.484-489, 2006.

HEBER, A.; JONES, D.; SUTTON, A. Indoor air quality: Controlling ammonia gas in swine buildings. Purdue University Cooperative: Extension Service. Disponível em:

<http://cdc.gov/niosh/nasd/docs4/in98003.html> Acesso em: 20 ago. 2002.

JÁCOME, I.M.T.D.; FURTADO, D.A.; LEAL, A.F. Avaliação de índices de conforto térmico de instalações para poedeiras no nordeste do Brasil. Revista Brasileira de Engenharia Agrícola e Ambiental, Campina Grande, v.11, n.5, p.527-531, 2007.

KIEFER, C.; FERREIRA, A.S.; OLIVEIRA, R.F.M. de; DONZELE, J.L.; BRUSTOLINI, P.C.; SILVA, F.C.O. Exigência de metionina mais cistina digestíveis para suínos machos castrados mantidos em ambiente de alta temperatura dos 30 aos $60 \mathrm{~kg}$. Revista Brasileira de Zootecnia, Viçosa-MG, v.34, n.1, p.104-111, 2005.

MANNO, M.C.; OLIVEIRA, R.F.M.; DONZELE, J. L.; OLIVEIRA, W.P.; VAZ, R.G.M.V.; SILVA, B.A.N.; SARAIVA, E.P.; LIMA, K.R.S. Efeito da temperatura ambiente sobre o desempenho de suínos dos 30 aos 60 kg. Revista Brasileira de Zootecnia, Viçosa-MG, v.35, n.2, p.471-477, 2006.

NR-15 Brasil. Ministério do Trabalho, Portaria no 3.214 de 8 de Junho de 1978: Normas regulamentadoras relativas a segurança e medicina do trabalho. In: Manual de Legislação de Atlas de Segurança e Medicina do Trabalho. 33.ed. São Paulo: Atlas, 1996. 523 p. 
PAULO, R.M.; TINÔCO, I.F.F.; OLIVEIRA, P.A.V.; SOUZA, C.M. BAÊTA, F.C.; CECON, P.R. Avaliação da amônia emitida de camas sobrepostas e piso concretado utilizados na criação de suínos, Revista Brasileira de Engenharia Agrícola e Ambiental, Campina Grande, v.13, n.2, p.210213, 2008.

SAEG - SISTEMA PARA ANÁLISE ESTATÍSTICA E GENÉTICA. Fundação Artur Bernardes, Versão 5.0. Viçosa: UFV, 1993. (Reg. 07517-5).

SAMPAIO, C.A.P.; NÄÄS, I.A.; BARACHO, M.S.; SALGADO, D.D. Avaliação de poluentes aéreos em instalações de creche e terminação de suínos. Ciência Rural, Santa Maria, v.37, n.2, p.488-494, 2007b.

SAMPAIO, C.A.P.; NÄÄS, I.A.; NADER, A. Gases e ruídos em edificações para suínos: Aplicação das normas NR-15 e ACGIR. Engenharia Agrícola, Jaboticabal, v.25, n.1, p.10-18, 2005.

SAMPAIO, C.A.P.; NÄÄS, I.A.; SALGADO, D.D. Amônia, gás sulfídrico, metano e monóxido de carbono na produção de suínos. Revista de Ciências Agroveterinárias, Lages, v.5, n.2, p.156-164, 2006.

SAMPAIO, C.A.P.; NÄÄS, I.A.; SALGADO, D.D. Bem-estar do trabalhador em espaços confinados de produção animal. Revista Brasileira de Engenharia de Biossistemas, Campinas, v.3, n.3, p.237-243, 2009.

SAMPAIO, C.A.P; NÄÄS, I.A.; SALGADO, D.D.; QUEIRÓS, M.P.G. Avaliação do nível de ruído em instalações para suínos. Revista Brasileira de Engenharia Agrícola e Ambiental, Campina Grande, v.11, n.4, p.436-440, 2007a.

SILVA, K.O.; NÄÄS, I.A.; TOLON, Y.B.; CAMPOS, L.S.L.; SALGADO, D.D. Medidas do ambiente acústico em creche de suínos. Revista Brasileira de Engenharia Agrícola e Ambiental, Campina Grande, v.11, n.3, p.339-344, 2007.

SILVEIRA, N.A.; NÄÄS, I.A.; MOURA, D.J. de.; SALGADO, D.D. Ambiência aérea em maternidade e creche de suínos. Engenharia Agrícola, Jaboticabal, v.29, n.3, p.348-357, 2009.

TINÔCO, I.F.F.; SOUZA, C.M.; OLIVEIRA, P.A.V. de.; PAULO, R.M.; CAMPOS, J.A.; CARVALHO, C da C.S.; CORDEIRO, M.B. Avaliação do índice de temperatura do globo negro e umidade e desempenho de suínos nas fases de crescimento e terminação criados em sistemas em cama sobrepostas em condições de verão. Revista Brasileira de Zootecnia, Viçosa, v. 38, n.5, p.1624-1629, 2007 (supl.).

TOLON, Y.B.; BARACHO, M.S.; NÄÄS, I.A.; ROJAS, M.; MOURA, D.J. Ambiência térmica, aérea e acústica para reprodutores suínos. Engenharia Agrícola, Jaboticabal, v.30, n.1, p.1-13, 2010.

TURCO, S.H.N.; BAÊTA, F.C.; CARDOSO, R.M.; CECON, P.R.; SOUZA, C.F. Utilização da ventilação forçada e resfriamento adiabático localizados em maternidades de suínos. In:

CONGRESSO BRASILEIRO DE ENGENHARIA AGRÍCOLA, 24., 1995, Viçosa. Anais... Viçosa: SBEA/UFV, 1995. v.1, p.1-12.

TURCO, S.H.N.; FERREIRA, A.S. F. da C.; AGUIAR, M.A.; CECON, P.C.; ARAÚJO, G.G.L. Avaliação térmica ambiental de diferentes sistemas de acondicionamento térmico em maternidades suinícolas. Revista Brasileira de Zootecnia, Viçosa, v.27, n.5, p.974-981, 1998.

VAREJÃO-SILVA, M.A. Meteorologia e climatologia. Brasília: Gráfica Editora Stilo, 2000, 532 p. 